УДК 636.4.082

(C) 2017

Войтенко А. М., здобувач

(науковий керівник - кандидат сільськогосподарських наук Л. В. Вишневський)

Інститут розведення і генетики тварин імені М. В. Зубця НААН

\title{
ПРОДУКТИВНІСТЬ КОРІВ І ТЕЛИЦЬ АЙРШИРСЬКОЇ ПОРОДИ В УМОВАХ ПОЛТАВЩИНИ
}

\section{Рецензент - доктор сільськогосподарських наук А. А. Поліщук}

\begin{abstract}
Проведено аналіз продуктивності ремонтних телиць та корів айрширської породи за їх розведення в умовах Полтавщчини та визначена можливість підвищення генетичного потенціалу тварин за врахування низки чинників. Визначено, щзо в стаді утримуються дочки бугаӥв 10 ліній, які мають різну племінну цінність, щзо обумовлюе мінливість господарськи корисних ознак тварин. Телиці характеризуються нерівномірністю росту за найбільш інтенсивного збільшення абсолютного і середньодобового приростів у період дванадияти-вісімнадияти місячів. Доведено, щзо корови айрширської породи, маючи в середньому по стаду надій за 305 днів лактації на рівні 6460 кг, підвищують надої зі збільшенням кількості лактацій. На фоні досить високої молочної продуктивності корів у стаді є серйозні проблеми із відтворенням.
\end{abstract}

Ключові слова: продуктивність, корови, теличі, айриирська порода.

Постановка проблеми. Сучасний розвиток молочного скотарства в Україні, як власне і в інших країнах світу, нерозривно пов'язаний із підвищенням рентабельності та ефективності галузі за рахунок зростання продуктивності тварин та зниженням витрат на виробництво молока $[7,9,10,12]$. Наявні в Україні породи великої рогатої худоби останнім часом удосконалюються за рахунок селекційного матеріалу кращого світового генофонду, який має високий генетичний потенціал продуктивності. У сумі 3 належними технологічними чинниками такий підхід сприяє поліпшенню господарськи корисних ознак великої рогатої худоби та підвищує ефективність галузі. Проте інтенсифікація галузі молочного скотарства на фоні підвищення продуктивності тварин приводить до витіснення 3 ринку порід, які $є$ не численними та мають нижчу продуктивність, порівняно із комерційними породами [4]. Наразі в Україні до нечисленних відносять айрширська порода великої рогатої худоби, яка утримується лише в двох племінних господарствах і характеризується значною мінливістю господарськи корисних ознак. А враховуючи, що вона залучена в процес виробництва продукції тваринництва і є складовою племінних ресурсів галузі тваринництва, виникає нагальна потреба вивчення основних біологічних ознак тварин 3 тим, щоб у подальшому відпрацювати основні селекційно-технологічні чинники, які сприятимуть підвищенню генетичного потенціалу тварин.

Аналіз останніх досліджень і публікацій, у яких започатковано розв'язання проблеми. Серед основних завдань галузі молочного скотарства, які передбачені на період 2013-2020 pp., $\epsilon$ збільшення обсягу виробництва та підвищення якості молока, підвищення генетичного потенціалу продуктивності тварин, створення нових та удосконалення існуючих стад, ліній, родин, типів та порід, придатних до сучасних технологій тощо. Вирішення цих завдань без визначення основних методів селекції 3 кожною породою великої рогатої худоби неможливо.

Загальновідомо, що на продуктивність тварин впливає генотип, умови їх розведення, природно-кліматична зона, племінна цінність батьків, лінійна належність, спадковість, екстер'єр, вік, жива маса, система та спосіб утримання, мікроклімат приміщень, способи приготування і роздавання корму, рівень та повноцінність годівлі, способи доїння та багато інших чинників [1-3, 6, $8,11-14]$. 3 урахуванням чого молочній худобі потрібно створити такі умови, в яких би вони почували себе комфортно і забезпечували притаманний для них генетичний потенціал продуктивності.

На Полтавщині розводиться п'ять порід великої рогатої худоби [5], серед яких не численною $\epsilon$ популяція айрширської породи. Дана порода на Полтавщині розводиться лише в умовах Державного підприємства «Дослідне господарство імені Декабристів» Інституту свинарства та АПВ Миргородського району Полтавської області й удосконалюється за рахунок інтенсивного використання бугаїв-поліпшувачів айрширської породи $з$ Фінляндії та Росії, а також споріднених порід, що не сприяє консолідації стада, ускладнює розведення за лініями та не завжди забезпечує підвищення генетичного потенціалу продук- 
тивності, особливо за якісними показниками.

3 огляду на це, оцінка господарськи корисних ознак тварин айрширської породи в умовах Полтавщини $є$ актуальною, оскільки сприятиме коригуванню методів селекції та визначенню впливу різних факторів на формування продуктивності тварин.

Мета досліджень - провести оцінку господарськи корисних ознак айрширської породи великої рогатої худоби в умовах Полтавщини та розробити пропозиції щодо підвищення їх продуктивності методами селекції.

Завдання досліджень - вивчити генеалогічну структуру стада, прирости ремонтних телиць під час вирощування, молочну продуктивність та відтворну здатність корів.

Матеріал і методи досліджень. Дослідження проведені в умовах Державного підприємства «Дослідне господарство імені Декабристів» Інституту свинарства та АПВ Миргородського району Полтавської області на ремонтних телицях i коровах айрширської породи. Генеалогічна структура стада визначена за лініями бугаїв, сперма яких використовувалася в стаді для відтворення маточного поголів'я. Молочна продуктивність визначена за надоями корів за 305 днів першої, другої, третьої та старше лактації, вмістом та кількістю молочного жиру і білку в молоці за низки лактацій. Відтворна здатність визначалася за тривалістю сервіс-періоду, сухостійного та між отельного періоду. Закономірності росту ремонтних телиць визначали за їх приростами протягом вирощування 3 шести до 18місячного віку.

Результати досліджень. Аналіз айрширської породи великої рогатої худоби в племінному репродукторі ДП «ДГ ім. Декабристів» Інституту свинарства та АПВ дав змогу встановити, що стадо формувалося шляхом поглинального схрещування місцевої симентальської породи монбельярдською і голштинофрізькою породами, а $з$ 80-х років минулого століття наявну популяцію поліпшували айрширською породою 3 частковим використанням голштинської породи. В результаті такого схрещування в генотипі частини тварин присутня умовна частка кровності вищевказаних порід, яка проявляється не лише в їх екстер'єрному типі, але і продуктивності.

Наразі тварини айрширської породи даного племінного репродуктора відносяться до ліній Мілкмена, Бруно, Партнера, Ворко, Келлі, Келога, Рейма, Торпана, Урхо еранта і Ханнулана яюскарі. Селекційний індекс бугаїв-плідників даних ліній, яких використовували для відтворення маточного поголів'я корів айрширської породи в стаді племінного репродуктора, варіює від CI +150 до $\mathrm{CI}+1582$, узгоджуючись із різною продуктивністю їх дочок.

Оцінюючи ремонтних телиць у процесі їх вирощування, можна зробити висновок, що найбільш інтенсивно тварини збільшують живу масу 3 дванадцяти до вісімнадцяти місяців, підтвердженням чого є показники абсолютного та середньодобового приростів (табл. 1). Зворотну тенденцію мали показники відносного приросту, засвідчуючи, що вища напруженість росту характерна для телиць у період їх вирощування від шести до дванадцятимісячного віку.

За останню закінчену лактацію у 2016 році корови айрширської породи на Полтавщині в середньому по стаду мали надій 6460 кг із вмістом жиру в молоці $3,8 \%$ та білку - $3 \%$. Надій корів мав тенденцію до підвищення зі збільшенням лактацій, причому різниця надоїв у корів між першою i другою лактацією становила 432 кг, а між другою та третьою і старше 300 кг. Молочна продуктивність корів, оцінених за першу та вищі лактації показана в таблиці 2.

\section{1. Прирости ремонтних телиць айрширської породи}

\begin{tabular}{|c|c|c|c|}
\hline Вік тварин, міс. & Абсолютний приріст, кг & Відносний приріст, \% & Середньодобовий приріст, г \\
\hline $6-12$ & 97,0 & 63,0 & 538 \\
\hline $12-18$ & 109,0 & 43,4 & 605 \\
\hline $6-18$ & 206,0 & 133,8 & 564 \\
\hline
\end{tabular}

2. Молочна продуктивність корів айриирської породи

\begin{tabular}{|c|c|c|c|}
\hline \multirow{2}{*}{ Показники } & \multicolumn{3}{|c|}{ Лактація } \\
\cline { 2 - 4 } & перша & друга & третя і старше \\
\hline Надій, кг & 6085 & 6517 & 6817 \\
\hline Вміст молочного жиру, \% & 3,85 & 3,82 & 3,82 \\
\hline Кількість молочного жиру, кг & 234,3 & 248,9 & 260,4 \\
\hline Вміст молочного білку, \% & 2,96 & 2,97 & 2,97 \\
\hline Кількість молочного білку, кг & 180,1 & 193,6 & 202,5 \\
\hline
\end{tabular}


Вміст молочного жиру і білку в молоці в цілому не залежав від величини надою і практично не різнився за лактаціями. Кількість молочного жиру та білку збільшувалася із лактацією, побічно корелюючи із надоями корів.

Нашими дослідженнями встановлено, що в стаді $\epsilon$ деякі проблеми із відтворенням, які приводять до того, що частка корів від першого плідного осіменіння становить не більше $60 \%$, а середній вік першого парування телиць здебільшого не нижче 18 місяців. Не узгоджується із можливістю щорічного одержання теляти від корови і тривалість міжотельного та сервіс-періоду. У $13 \%$ корів виявлено важкий перебіг отелень, який в більшості приводить до мертвонародженості телят. Проблеми із відтворенням $є$ одними із основних, за якими корів вибрако-

\section{БІБЛІОГРАФІЯ}

1. Борисовський В. А. Продуктивні якості корів айрширського стада залежно від їх лінійної належності / В. А. Борисовський // Науковотехнічний бюлетень Інституту тваринництва. - Х., 2008. - №97. - С. 190-193.

2. Братушка Р. В. Вплив паратипних факторів на відтворну здатність корів сумського внутрішньопородного типу української чорно-рябої молочної породи / Р. В. Братушка // Вісник аграрної науки. - 2012. - №9. - С. 73-75.

3. Взаємозв'язок екстер'єрних особливостей тварин з їх молочною продуктивністю / [Сірацький Й. З., Ференц Л. В., Зозуля О. І. та ін.] // Вісник Сумського НАУ. - Суми, 2008. - Вип. 6 (14). C. $123-130$.

4. Войтенко С. Л. Моніторинг галузі молочного скотарства та виживаність локальних вітчизняних порід / С. Л. Войтенко, Л.В.Вишневський // Вісник Житомирського національного агроекологічного університету. - 2015. - №2 (52). - Т.3. - С. 3-9.

5. Войтенко С. Л. Молочна продуктивність та відтворна здатність корів української чорно-рябої молочної породи Полтавщини / С. Л. Войтенко, М. О. Петренко, Б. С. Шаферівський, І. М. Желізняк // Вісник Сумського Національного аграрного університету. - 2017. - Вип. 5/1 (31). - С. 36-44.

6. Воспроизводительная способность коров молочных пород и их экономическая оценка / [Сударев Н. П., Абылкасымов Д. А., Ионова Л. В. и др.] // Зоотехния. - 2012. - №7. - С. 27-28.

7. Зубець М. В. Система племінної роботи як засіб виробництва при формуванні порід, що відповідають вимогам ринку / М. В. Зубець, С. Ю. Рубан // Розведення і генетика тварин : міжвід. темат. наук. зб. - 2010. - Вип. 44. - С. 3-10. вують зі стада.

Таким чином, аналіз стада айрширської породи великої рогатої худоби в племінному репродукторі ДП «ДГ ім. Декабристів» Інституту свинарства та АПВ Полтавської області дав змогу зробити висновок про досить високу молочну продуктивність корів на фоні проблем із відтворенням.

Висновок. На перспективу слід визначити продуктивність тварин айрширської породи у залежності від низки генотипових та паратипових чинників, сконцентрувавши основну увагу на впливі генотипу, плідника, лінії, умов утримання і годівлі.

Підвищуючи молочну продуктивність корів, слід пам'ятати про відтворну здатність та ії обумовленість.

8. Кузів M. I. Залежність молочної продуктивності корів української чорно-рябої молочної породи від живої маси в період їх вирощування / М. І.Кузів, Є. І. Федорович // Вісник Сумського Національного аграрного університету. - 2014. Вип. 2/2 (25). - С. 68-72.

9. Костенко $O$. Вирішальні фактори в молочному скотарстві / О. Костенко // Аграрний тиждень. 2015. - №4-5. - C. 74-75.

10. Ладика B. I. Молочне тваринництво України: стан та перспектива / В. І. Ладика, Л. В. Бондарчук // Вісник Сумського Національного аграрного університету. - 2014. - Вип. 2/2 (25). - С. 3-9.

11. Піддубна Л. Вплив генотипових та паратипових факторів на молочну продуктивність української червоно-рябої молочної худоби / Л. Піддубна // Тваринництво України. - 2014. - №3-4. - С. 11-14.

12. Стан і перспективи порідного удосконалення молочного скотарства i відновлення системи селекції бугаїв / [Бащенко М. І., Полупан Ю. П., Рубан С. Ю. та ін.] // Розведення і генетика тварин : міжвід. темат. наук. зб. - 2012. - Вип. 46. - С. 79-83.

13. Ставецька Р. В. Вплив генотипу бугаївплідників на господарськи корисні ознаки стада / Р. В. Ставецька // Вісник аграрної науки Причорномор'я. - Миколаїв, 2011. - Вип. 4 (64), Т. 4, Ч. 2. C. 86-91.

14. Федорович В. В. Залежність молочної продуктивності корів айрширської породи від їх відтворювальної здатності / В. В. Федорович, Н. П. Бабік // Збірник наукових праць Білоцерківського національного аграрного університету «Технологія виробництва і переробки продукції тваринництва». 2015. - №1 (113). - C. 79-84. 